\title{
Inorganic and organic nitrogen cycling in Chesapeake Bay: autotrophic versus heterotrophic processes and relationships to carbon flux
}

\author{
Deborah A. Bronk ${ }^{1, *}$, Patricia M. Glibert ${ }^{2}$, Thomas C. Malone ${ }^{2}$, Susan Banahan ${ }^{3}$, \\ Elisabeth Sahlsten ${ }^{4}$ \\ ${ }^{1}$ Department of Marine Sciences, University of Georgia, Athens, Georgia 30602-3636, USA \\ ${ }^{2}$ Horn Point Laboratory, University of Maryland Center for Environmental Science, PO Box 775, Cambridge, \\ Maryland 21613, USA \\ ${ }^{3}$ Coastal Oceans Office, NOAA, 1315 East-West Highway, Rm 15140, Silver Springs, Maryland 20910-3223, USA \\ ${ }^{4}$ Department of General and Marine Microbiology, University of Göteborg, Medicinaregatan 9C, S-41390 Göteborg, Sweden
}

\begin{abstract}
To define the role of dissolved organic nitrogen (DON) in Chesapeake Bay (USA) nitrogen cycling, we performed experiments in the mesohaline Chesapeake Bay during 3 seasons: May, during the mid to late spring bloom, August, when patchy summer blooms often develop, and October, after the fall overturn. Every $3 \mathrm{~h}$ for $30 \mathrm{~h}$ we measured ambient nitrogen concentrations and used ${ }^{15} \mathrm{~N}$ tracers to determine uptake and regeneration rates of $\mathrm{NH}_{4}{ }^{+}$and urea, uptake rates of $\mathrm{NO}_{3}{ }^{-}\left(\mathrm{NO}_{2}{ }^{-}\right.$was measured in October only), and rates of DON release due to $\mathrm{NH}_{4}{ }^{+}$uptake. Autotrophic production and dissolved organic carbon (DOC) release were determined simultaneously using ${ }^{14} \mathrm{C}$ tracer techniques to compare with nitrogen flux rates. We found that first, the water column nitrogen demand exceeded nitrogen regeneration in May but nitrogen regeneration was over 3 times greater than the nitrogen demand in October. Second, mean rates of autotrophic DON release were highest in May but heterotrophic release was more important in summer and fall. Third, during all 3 studies, the C:N ratio of DOC to DON release rates was 3.4 to 4.5, indicating release of nitrogen-rich compounds. Release of dissolved organic matter (DOM) with a low $\mathrm{C}: \mathrm{N}$ ratio was corroborated by an observed increase in DON concentrations from 7 to $42 \mu \mathrm{g}$-at. $\mathrm{N}^{-1}$ from May to August and a concomitant decrease in the C:N ratio of the ambient DOM pool from 36.6 to 8.8. These data suggest that Chesapeake Bay is primarily autotrophic in the spring, but becomes progressively more heterotrophic later in the year. These data also suggest that DON is an important intermediate in this transition and serves as a link between the allochthonous nitrogen-based autotrophic production in the spring and the autochthonous nitrogen-based heterotrophic system in the summer and fall.
\end{abstract}

KEY WORDS: Nitrogen - Chesapeake Bay - Dissolved organic nitrogen - Dissolved organic carbon C:N ratios

\section{INTRODUCTION}

Planktonic nutrient dynamics has been studied in Chesapeake Bay (USA) for several decades. The picture emerging from this work is a system that is predominantly autotrophic in the spring when large

·E-mail: dbronk@arches.uga.edu amounts of new nitrogen, primarily in the form of $\mathrm{NO}_{3}{ }^{-}$, enter the Bay via rivers (Malone et al. 1988, Smith \& Kemp 1995). As the year progresses, the Bay becomes more heterotrophic in character with a planktonic community increasingly dependent on regenerated forms of nitrogen either from the sediments or recycled within the water column (Malone et al. 1988, Smith \& Kemp 1995). Consistent with this scenario, seasonal phytoplankton biomass and pro- 
ductivity, integrated throughout the water column, are out of phase, with a spring accumulation of biomass fueled by riverine $\mathrm{NO}_{3}{ }^{-}$input and a summer productivity maximum fueled by benthic and water column nitrogen regeneration (Boynton \& Kemp 1985. Malone et al. 1988, Kemp \& Boynton 1992). The switch from a primarily autotrophic system to a primarily heterotrophic system is also accompanied by a change in the limiting factor of planktonic growth rates-phosphorus limitation predominates in the spring while nitrogen limitation predominates in the summer (Malone et al. 1996).

While the supply of new nitrogen, as $\mathrm{NO}_{3}{ }^{-}$, is greatest in the spring, maximum phytoplankton production, which is ultimately fueled by these spring-time nitrogen inputs, does not occur until summer (Kemp \& Boynton 1984j. The role dissolved organic nitrogen (DON) plays in this scenario is largely unknown because nutrient studies in the Bay have focused primarily on the availability and fluxes of dissolved inorganic nitrogen (DIN; e.g. Horrigan et al. 1990, Fisher et al. 1992). In batch cultures and a number of other aquatic environments, however, DON has been shown to be a dynamic component of the nitrogen cycle (Collos 1992, Collos et al. 1992, 1996, Bronk et al. 1994, López-Veneroni \& Cifuentes 1994, Slawyk \& Raimbault 1995). Specifically, in Chesapeake Bay we know that during the decline of the spring bloom, rates of DON release from phytoplankton can be quite high, and rates of uptake of recently released DON during these periods can rival rates of uptake of DIN (Bronk \& Glibert 1991, 1993a). In addition, one form of DON, urea, can be an important source of nitrogen for the biota of the Bay, in the spring contributing from $\sim 6 \%$ of the total nitrogen utilized in the northern reaches of the Bay to $>30 \%$ in the south (Glibert et al. 1995).

This study is part of a continuing effort to incorporate the DON pool into our understanding of Chesapeake Bay nutrient dynamics. We measured rates of nitrogen uptake and release during 3 seasons in the mesohaline reach of the Bay to provide detailed pictures of organic and inorganic nitrogen cycling in the water column. Our objectives were: (1) to determine the short-term variability (h) in rates of nitrogen uptake and release: (2) to compare gross $\mathrm{NH}_{4}{ }^{+}$uptake rates, which correct for ${ }^{15} \mathrm{~N}$ label lost to the DON pool, with traditionally measured net uptake rates (Bronk et al. 1994); (3) to compare DON release (assumed to be a primarily autotrophic process with the methods we employed) with $\mathrm{NH}_{4}{ }^{+}$and urea regeneration (assumed to be primarily heterotrophic in nature); and (4) to compare rates of nitrogen uptake and release with rates of carbon uptake and release over short-term and seasonal time scales.

\section{MATERIALS AND METHODS}

Field sampling. We occupied an anchor station in the mainstem of Chesapeake Bay (Station \#3 in Malone et al. 1991) on 15 to 16 May, 31 August to 1 September, and 20 to 21 October 1988. During each sampling period, near-surface water was collected every $3 \mathrm{~h}$ for $30 \mathrm{~h}$ with either an acid-washed Niskin bottle or a polyethylene bucket.

Concentrations and standing stocks. At each time point, water was first filtered through precombusted $\left(450^{\circ} \mathrm{C}\right.$ for $\left.2 \mathrm{~h}\right)$ Whatman $\mathrm{GF} / \mathrm{F}$ filters and flash frozen in liquid nitrogen for later determination of nutrient concentrations in the laboratory (within several weeks). Concentrations of $\mathrm{NO}_{3}{ }^{-}, \mathrm{NO}_{2}{ }^{-}$, and phosphate were determined with a Technicon AutoAnalyzer, concentrations of urea were measured with the urease method (Parsons et al. 1984), concentrations of $\mathrm{NH}_{4}{ }^{+}$ were measured manually with the phenol/hypochlorite technique (Parsons et al. 1984), and concentrations of DON were determined by the persulfate oxidation technique (Valderrama 1981). Water was also filtered through a $0.2 \mu \mathrm{m}$ Nuclepore filter for subsequent determination of the concentration of dissolved primary amines (DPA; Parsons et al. 1984). Concentrations of dissolved organic carbon (DOC) were measured with wet persulfate digestion as originally described by Menzel \& Vaccaro (1964) and as modified by McDowell et al. (1987). Concentrations of chlorophyll a (chl a) were measured according to the fluorometric technique in Parsons et al. (1984). Particulate nitrogen (PN) and particulate carbon (PC) were analyzed with a Control Equipment CHN analyzer.

Uptake and regeneration of inorganic nitrogen. At each time point, we used ${ }^{15} \mathrm{~N}$ tracer techniques to estimate nitrogen flux rates. We used nutrient concentrations from prior years to estimate the ${ }^{15} \mathrm{~N}$ additions that would yield about $10 \%$ enrichment over ambient levels. The initial atom \% enrichment of the substrate poo] was calculated based on the ambient concentration and the amount of ${ }^{15} \mathrm{~N}$ added. In the ${ }^{15} \mathrm{~N}$ mass balance, final atom \% enrichments were calculated in a similar fashion with the exception that the initial substrate concentration was corrected for the amount of substrate taken up during the incubation, based on the measured uptake rate. The target enrichment levels were achieved in May and October. Due to the highly variable nature of the ambient concentrations in August, however, enrichments were $31 \pm 17$ and $71 \pm$ $21 \%$ for $\mathrm{NH}_{4}{ }^{*}$ and $\mathrm{NO}_{3}{ }^{-}$, respectively.

Incubations were done in 11 polycarbonate bottles, in on-deck flow-through incubators under simulated in situ light and temperature conditions. Incubations were initiated within 20 min of sample collection, and all samples were incubated for $-0.5 \mathrm{~h}$; in high biomass 
waters such as Chesapeake Bay, this incubation time allows measurement of ambient rates while minimizing the risk of substrate depletion (Wheeler et al. 1982 , Glibert \& Capone 1993). At the end of the incubation we filtered only enough sample, through precombusted GF/F filters, to collect enough nitrogen on the filter for analysis; filtration times were $\sim 5 \mathrm{~min}$ in Mary and August and $10 \mathrm{~min}$ in October. Filters were subsequently dried at $50^{\circ} \mathrm{C}$, ampoulated, and analyzed by mass spectrometry (Glibert et al. 1991). We note that $\mathrm{GF} / \mathrm{F}$ filters retain autotrophic phytoplankton, including most picoplankton, and about $50 \%$ of the heterotrophic bacteria in Chesapeake Bay (Glibert et al. 1995). Therefore, our measurements include uptake by bacteria but likely do not represent total bacterial uptake.

The filtrate from the $\mathrm{NH}_{4}{ }^{+}$incubation was collected, split into 2 aliquots, and frozen for later determination of ${ }^{15} \mathrm{~N}$ atom $\%$ enrichment of the $\mathrm{NH}_{4}{ }^{+}$and $\mathrm{DON}$ pools (see below). The $\mathrm{NH}_{4}{ }^{+}$atom \% enrichment was determined by distillation and evaporation followed by mass spectrometric analysis. These data were used to calculate the rate of $\mathrm{NH}_{4}{ }^{+}$regeneration and to correct the $\mathrm{NH}_{4}{ }^{+}$uptake rates for isotope dilution (Glibert et al. 1982).

Uptake and regeneration of urea. Urea uptake rates were determined with the same ${ }^{15} \mathrm{~N}$ tracer techniques used to measure rates of inorganic nitrogen uptake. Enrichment levels were $-10 \%$ for May and October, and $\sim 25 \%$ for August. Rates of urea regeneration were determined from isotope dilution in parallel $250 \mathrm{ml}$ samples enriched with the same concentration of ${ }^{14} \mathrm{C}$ labeled urea (Hansell \& Goering 1989, Glibert \& Capone 1993). Urea uptake rates were corrected for isotope dilution.

Isolation of the DON pool. From the $\mathrm{NH}_{4}^{+}$incubation experiments, one of the aliquots of filtrate was filtered through a $0.2 \mu \mathrm{m}$ Nuclepore filter and frozen in liquid nitrogen for later processing. On shore, we measured the DON concentration, as above, and we passed $9 \mathrm{ml}$ of the remaining filtrate through ion retardation resin (BioRad $A G 11 \mathrm{~A} 8$ ), which removed inorganic ions (including $\mathrm{NH}_{4}{ }^{+}$and $\mathrm{NO}_{3}{ }^{-}$), leaving eluate containing the DON (Bronk \& Glibert 1991, 1993b). Eluates were boiled down to $-2 \mathrm{ml}$, blotted onto a precombusted GF/F filter, and analyzed by mass spectrometry (Bronk \& Glibert 1991).

We note that DOW Chemical has changed the manufacturing process of the BioRad AG 11 A8 resin within the last few years. As a result of the manufacturing change, the new resin now retains variable amounts of DON. This DON retention is believed to be due to an accumulation of an organic film on the resin beads during manufacturing (BioRad pers, comm.). The original resin, including the resin we used in this study, did not retain DON. We are presently investigating methods to manufacture the original form of the resin in the laboratory (Bronk unpubl. data)

Calculation of uptake rates. Uptake rates of $\mathrm{NO}_{3}$ and $\mathrm{NO}_{2}$ were calculated according to the commonly used equations introduced by Dugdale \& Goering (1967):

$$
\rho=\frac{\mathrm{PN} \text { at } \% \mathrm{xs}}{\mathrm{DIN} \text { at } \% \times \mathrm{xs} \times \text { Time }} \times[\mathrm{PN}]
$$

where $\rho$ is the uptake rate in $\mu g$-at. $\mathrm{N}^{-1} \mathrm{~h}^{-1}$; PN at $\% \mathrm{xs}$ is the ${ }^{15} \mathrm{~N}$ atom \% enrichment of the PN minus atmospheric ${ }^{15} \mathrm{~N}$ enrichment (typically 0.365 ) in atom \%; DIN at $\% x$ is the initial enrichment of the DIN pool minus atmospheric ${ }^{15} \mathrm{~N}$ enrichment in atom $\%$; time is the period of incubation in hours; and [PN] is the concentration of $\mathrm{PN}$ in the sample at the end of the incubation in $\mu \mathrm{g}$-at. $\mathrm{N}^{-1}$. In the case of $\mathrm{NH}_{4}{ }^{+}$and urea, the at $\%$ xs in the denominator was corrected for isotopic dilution as described by Glibert et al. (1982) for $\mathrm{NH}_{4}{ }^{+}$and Hansell \& Goering (1989), as modified by Glibert \& Capone (1993), for urea. These rates are net uptake rates as they represent the ${ }^{15} \mathrm{~N}$ retained within the particulate material at the end of the incubation (Bronk et al. 1994).

To calculate the gross $\mathrm{NH}_{4}^{+}$uptake rate, we first calculated the gross atom \% enrichment of the PN, which includes ${ }^{15} \mathrm{~N}$ measured in both the PN and the extracellular DON pools with the equation:

$$
\begin{aligned}
& \mathrm{PN}_{\mathrm{G}} \text { at } \% \mathrm{xs}= \\
& \frac{([\mathrm{PN}] \times \mathrm{PN} \text { at } \% \times \mathrm{xs})+([\mathrm{DON}] \times \mathrm{DON} \text { at } \% \times s)}{[\mathrm{PN}]}
\end{aligned}
$$

where $\mathrm{PN}_{\mathrm{G}}$ at $\% \mathrm{xs}$ is the gross atom \% enrichment of the PN pool modified to include ${ }^{15} \mathrm{~N}$ accumulated in the extracellular DON pool, minus atmospheric ${ }^{15} \mathrm{~N}$ enrichment in atom \%; $[\mathrm{PN}]$ and [DON] are the concentrations of $\mathrm{PN}$ and DON respectively in $\mu \mathrm{g}$-at. $\mathrm{N}^{-3}$; $\mathrm{PN}$ and DON at \%xs are the atom \% enrichments of the PN and DON pools minus atmospheric ${ }^{15} \mathrm{~N}$ enrichment in atom $\%$. To calculate the final gross uptake rate $\left(\rho_{\mathrm{G}}\right)$ we substitute $\mathrm{PN}_{\mathrm{G}}$ at\%xs (from Eq. 2) for $\mathrm{PN}$ at $\% \mathrm{xs}$ in Eq. (1) (Bronk et al. 1994, Collos pers. comm.) to generate the following equation:

$$
p_{\mathrm{G}}=\frac{([\mathrm{PN}] \times \mathrm{PN} \text { at } \% \times s)+([\mathrm{DON}] \times \mathrm{DON} \text { at } \% \mathrm{xs})}{\mathrm{DIN} \text { at } \% \times \mathrm{xs} \times \text { Time }}
$$

where $\rho_{\mathrm{G}}$ is the gross uptake rate in $\mu \mathrm{g}$-at. $\mathrm{N}^{-1} \mathrm{~h}^{-1}$ and other terms are as described above.

Laws (1985) proposed that a distinction be made between an assimilation rate, $A$, and an apparent uptake rate, $U$. The traditionally determined rate, which we term the net uptake rate, is virtually identical to the assimilation rate described by Laws (1985). However, our calculation of gross $\mathrm{NH}_{4}{ }^{+}$uptake rates 
and the apparent uptake rate, $U$, are not the same. Our calculations are based on a direct measurement of the ${ }^{15} \mathrm{~N}$ content in the DON pool, whereas $U$ is not.

Calculation of DON release rates. In the ${ }^{15} \mathrm{NH}_{4}{ }^{+}$ incubations, the rate of DON release was calculated by subtracting the net $\mathrm{NH}_{4}{ }^{+}$uptake rate (Eq. 1) from the gross $\mathrm{NH}_{4}{ }^{+}$uptake rate (Eq. 3; Bronk et al. 1994). The DON release rates we present here are net rates, because they are a measure of the DON which has been released from the phytoplankton and is present in the extracellular pool at the end of the incubation. We note that this DON release rate only represents DON release that results from $\mathrm{NH}_{4}{ }^{+}$uptake. If the atom $\%$ enrichments of the DON pool had been determined for incubations with other inorganic nitrogen substrates, the same formulations could be used.

The method of determining the rate of DON release presented here differs from a method previously reported (Bronk \& Glibert 1991, 1993b). Whereas both methods require isolation of the extracellular DON pool, the method presented here does not require a separate analysis of the ${ }^{15} \mathrm{~N}$ content of the intracellular organic pool, and is thus considerably less labor intensive.

To compare flux rates with changes in ambient nitrogen pools, we calculated cumulative daily nitrogen flux rates by integrating the hourly rates, measured every $3 \mathrm{~h}$, over a $24 \mathrm{~h}$ period by assuming that the measured rate was constant for the $-3 \mathrm{~h}$ that separated the individual rate measurements. The resulting rate is the mass of nitrogen taken up or released during a $24 \mathrm{~h}$ period expressed as $\mu \mathrm{g}$-at. $\mathrm{N}^{-1} \mathrm{~d}^{-1}$. We note that nitrogen flux rates were measured at $-09: 00$ and 12:00 h on 2 consecutive days; both of the rates measured at 09:00 and 12:00 h were averaged and then used in the calculation to obtain the integrated flux for a $24 \mathrm{~h}$ period.

Error analysis. We were unable to perform duplicate ${ }^{15} \mathrm{~N}$ incubations. To estimate the variability associated with the final rate measurements, a propagation of error analysis was performed as described in Bevington (1969). The variance of the nutrient concentrations and atom \% enrichments were calculated from replicate analyses (i.e. duplicates or triplicates depending on the analysis). This method provides a conservative cstimate of the variance.

Uptake and release of carbon. Details of the methods used to determine rates of carbon uptake and DOC release are described in Malone et al. (1991). In brief, whole water and prefractionated $(1 \mu \mathrm{m}$ Nuclepore filter) samples were incubated with ${ }^{14} \mathrm{C}$-labeled $\mathrm{NaHCO}_{3}$ for $6 \mathrm{~h}$, beginning at dawn, and subsamples were withdrawn on an hourly basis. The rates reported in Malone et al. (1991), and used in this paper, were calculated from the slope of the least squares regression line generated during the $6 \mathrm{~h}$ time-course. To calculate daily rates, we multiplied the rate determined from the least squares regression by $16 \mathrm{~h}$ if the process was light dependent [i.e. dissolved inorganic carbon (DIC) uptake] or $24 \mathrm{~h}$ if it was not light dependent (i.e. DOC release). The amount of label incorporated was also measured after $24 \mathrm{~h}$ to determine autotrophic production for the whole water samples. The difference between hourly rates, determined in the short-term incubations, and the $24 \mathrm{~h}$ rates was used to estimate the respiration rate

\section{RESULTS}

\section{Ambient environmental conditions}

Changes in the concentrations of inorganic nutrients were generally consistent with previous reports for Chesapeake Bay during spring, summer, and fall (Fig. 1A-F). In May, mean $\mathrm{NO}_{3}^{-}$concentrations approached $30 \mu \mathrm{g}$-at. $\mathrm{N}^{-1}$, reflecting the large influx of nitrogen-rich freshwater into the Bay from the Susquehanna River; concentrations of $\mathrm{NO}_{3}^{-}$were depleted during the other months in the study (Fig. 1D-F). In contrast, concentrations of the regenerated forms of nitrogen $\left(\mathrm{NH}_{4}{ }^{+}\right.$, urea, and DPA) were relatively low in May, and the highest $\mathrm{NH}_{4}{ }^{+}$concentrations were measured in October (Fig, 1A-C). Large variations in urea and DPA were not observed between seasons, suggesting a tight coupling between uptake and regeneration processes. Alternatively, concentrations of the bulk DON pool more than doubled from May to August, before decreasing again in October (Fig. 1D-F) Phosphate concentrations were $0.10 \pm 0.06$ in May, $0.18 \pm 0.08$ in August, and $0.07 \pm 0.02$ in October. Ambient DIN:DIP ratios ranged from 84 to 430,7 to 57 , and 74 to 184 in May, August, and October, respectively.

In August, concentrations of $\mathrm{NO}_{2}^{-}$were very high, nearly reaching $10 \mu \mathrm{g}$-at. $\mathrm{N}^{-1}$ (Fig. 1E). The day before our August sampling began, the remnants of a tropical depression, 'Chris', passed through the Bay. Wind events can trigger a series of short-lived nutrient and microbial processes. In particular, wind mixing of $\mathrm{NH}_{4}{ }^{+}$rich water, likely of sedimentary origin, across the pycnocline may have led to enhanced rates of nitrification; this response to storm-induced mixing in Chesapeake Bay has also been noted in McCarthy et al. (1984) and Horrigan et al. (1990).

The highest and most variable concentrations of PN and chl a were observed in August, and the lowest concentrations were seen in October (Fig. 1G-I). The mean and standard deviations of PN:chl a ratios were $1.0 \pm 0.2,1.3 \pm 0.3$, and $0.4 \pm 0.1$ for May, August, and October, respectively, suggesting that the PN was composed largely of living phytoplankton or phyto- 
Fig. 1 Concentrations of $\mathrm{NH}_{4}{ }^{+}(\bullet)$, urea $(\mathbf{\nabla})$, dissolved primary amines (DPA: $\nabla$ ), $\mathrm{NO}_{3}^{-}(\bullet), \mathrm{NO}_{2}^{-}$ $(\diamond)$, dissolved organic nitrogen (DON, o), chlorophyll a (chl, घ), and particulate nitrogen ( $P N, \mathbf{\Delta})$ versus time of day for 3 diel studies performed in the mesohaline Chesapeake Bay. The black bars denote the dark period
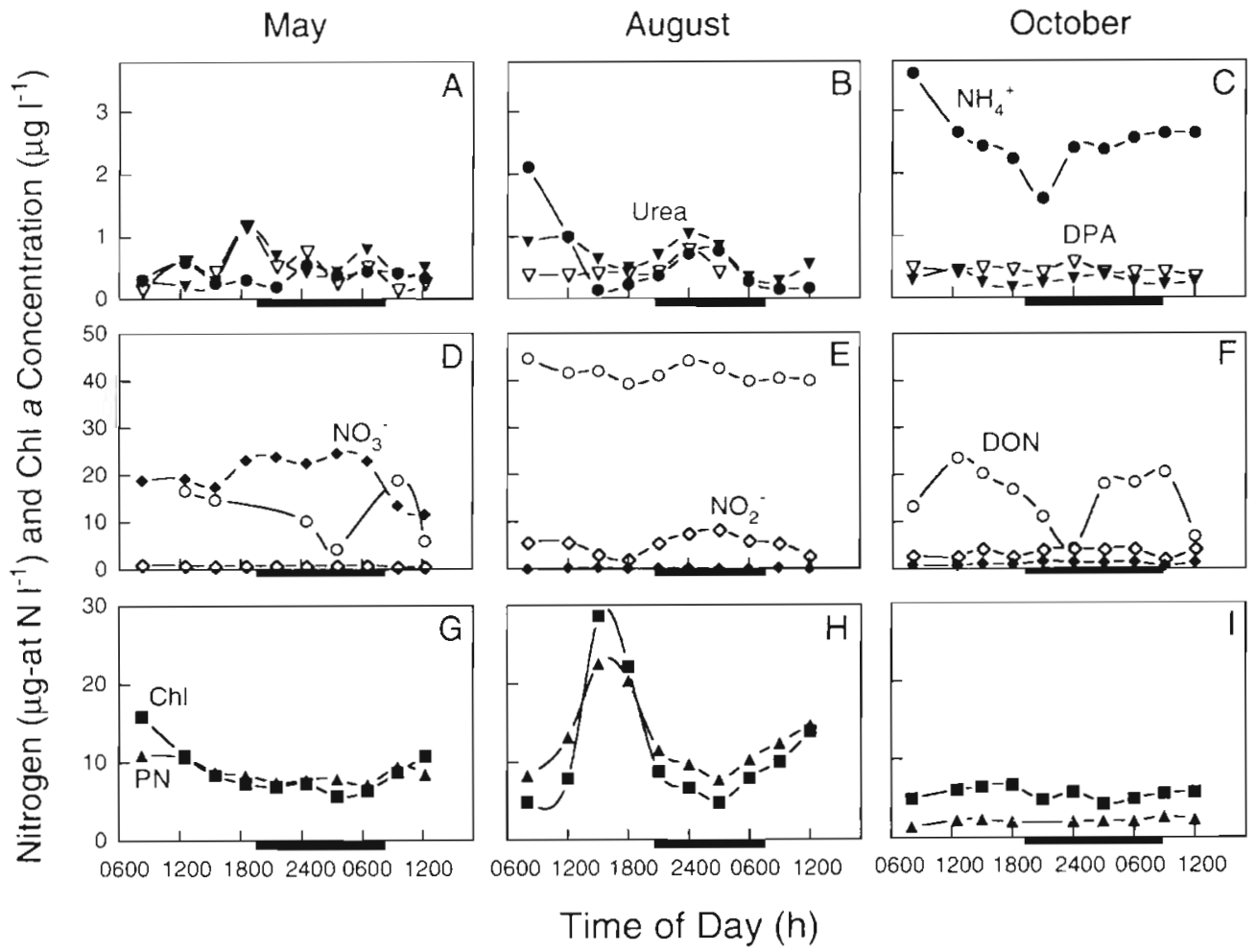

plankton-derived material (McCarthy \& Nevins 1986). During August, we observed a patch of 'brown' water between 12:00 and 18:00 h, coincident with substantial increases in the concentration of PN and chl $a$, and decreases in the concentrations of $\mathrm{NH}_{4}{ }^{+}, \mathrm{NO}_{2}{ }^{-}$, and urea (Fig. 1). Sporadic and localized dinoflagellate blooms often develop in the summer in Chesapeake Bay (Loftus et al. 1972, Seliger et al. 1981), and it is likely that such a patchy bloom passed through our sampling site on the afternoon of Day 1 and returned 12 h later; such a patch may have either been carried with the tide or migrated vertically.

\section{Rates of nitrogen uptake and release}

Mass balances of ${ }^{15} \mathrm{~N}$ label were reasonably achieved for all uptake experiments. For the $\mathrm{NO}_{3}{ }^{-}$and urea incubations, $100 \pm 0.3$ and $100 \pm 3.8 \%$ of the ${ }^{15} \mathrm{~N}$ label was accounted for in the combined PN and substrate pools at the end of the incubations. For the $\mathrm{NH}_{4}{ }^{+}$ measurements, $105 \pm 27 \%$ of the ${ }^{15} \mathrm{~N}$ label was accounted for in the combined $\mathrm{PN}_{1} \mathrm{NH}_{4}{ }^{+}$, and DON pools at the end of the incubations ${ }^{15} \mathrm{~N}$ in the DON pool alone accounted for $15 \pm 13,4 \pm 4$, and $1 \pm 1 \%$ of the total ${ }^{15} \mathrm{~N}$ recovered in May, August, and October, respectively.

In general, rates of nitrogen uptake were highest overall in August and lowest in October (Fig. 2). We normalized uptake and DON release rates to ambient chl a concentrations (units were $\mu \mathrm{g}$-at. $\mathrm{N} \mu \mathrm{g}^{-1} \mathrm{chl} \mathrm{h}^{-1}$; data not shown) and found the same patterns over the course of the $30 \mathrm{~h}$ study as we present in Figs. 2 \& 3A-F. During May, uptake rates of all measured substrates were comparable, and $\mathrm{NO}_{3}^{-}$uptake rates were the highest we measured during the 3 cruises. In August, however, net uptake rates varied by a factor of 15 (Fig. 2). Unfortunately, rates of $\mathrm{NO}_{2}^{-}$uptake were not determined in August when $\mathrm{NO}_{2}{ }^{-}$concentrations were high. By October, $\mathrm{NH}_{4}{ }^{+}$was the dominant nitrogen form used.

Relative to uptake rates, the mean rates of DON release were similar between seasons (Fig, 3D-F). The cumulative amount of DON released during $24 \mathrm{~h}$ was highest in May and decreased throughout successive cruises $\left(1.73,1.29\right.$, and $0.82 \mu \mathrm{g}$-at. $\mathrm{N}^{-1} \mathrm{~d}^{-1}$ for May, August, and October, respectively). We note that we did not measure the production of DON during incubations with $\mathrm{NO}_{3}^{-}$or urea. Therefore, our estimates of DON release would be an underestimate of the total DON release rate. Mass balances of ${ }^{15} \mathrm{~N}$ for experiments with $\mathrm{NO}_{3}{ }^{-}$and urea, done in $\mathrm{May}$ and October, showed complete recovery of the ${ }^{15} \mathrm{~N}$ we added, and so we have no empirical evidence for significant rates of DON release; direct measurements are needed to confirm this in future studies.

In all 3 studies, rates of DON release measured at dawn and dusk appeared to be higher than those mea- 
sured at other times during the day, though the relationship was not significant at the $95 \%$ confidence level (Fig. 4). Cellular metabolites could be released as the cells shift from light dependent to non light dependent reactions and vice versa. It is also possible that this pattern reflects greater grazing activity at dawn and dusk, and thus greater release due to 'sloppy feeding'.

The cumulative amount of $\mathrm{NH}_{4}^{+}$regenerated per liter during $24 \mathrm{~h}$ was lowest in May and highest in August $\left(1.7,11.0\right.$, and $8.3 \mu g$-at. $\mathrm{N}^{-1} \mathrm{~d}^{-1}$ for May, August, and October, respectively). Rates of regenera-
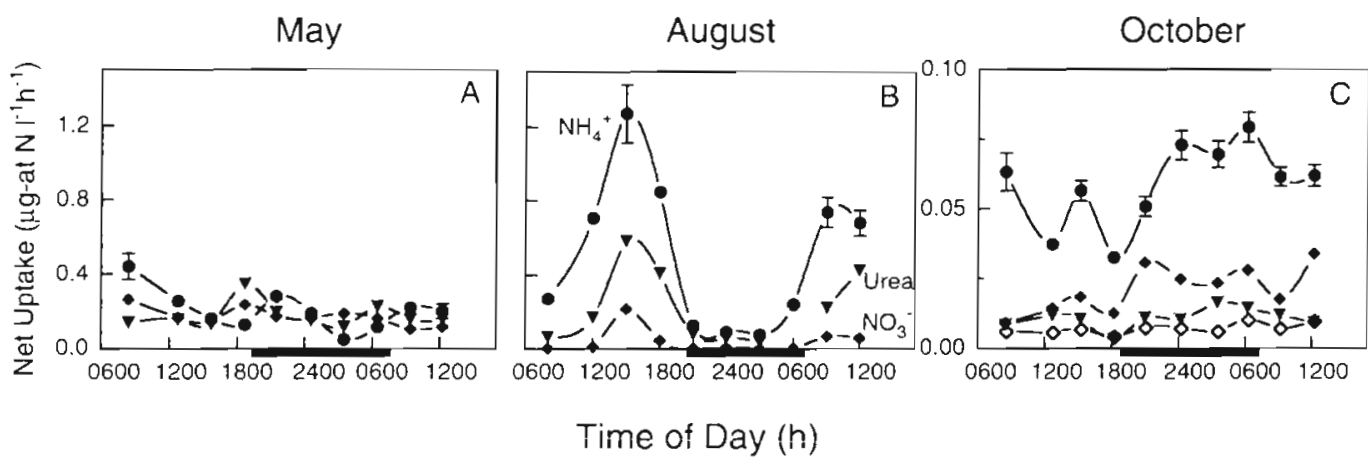

Fig. 2. Net uptake rates of $\mathrm{NH}_{4}{ }^{+}(\bullet)$, urea $(\nabla), \mathrm{NO}_{3}^{-}(\bullet)$, and $\mathrm{NO}_{2}^{-}(\diamond$, October only) versus time of day for 3 diel studies performed in the mesohaline Chesapeake Bay. The black bars denote the dark period. Note the large change in scale in the October graph. Data are plotted with error bars indicating standard deviations; where error bars are not shown, error bars are smaller than the symbols
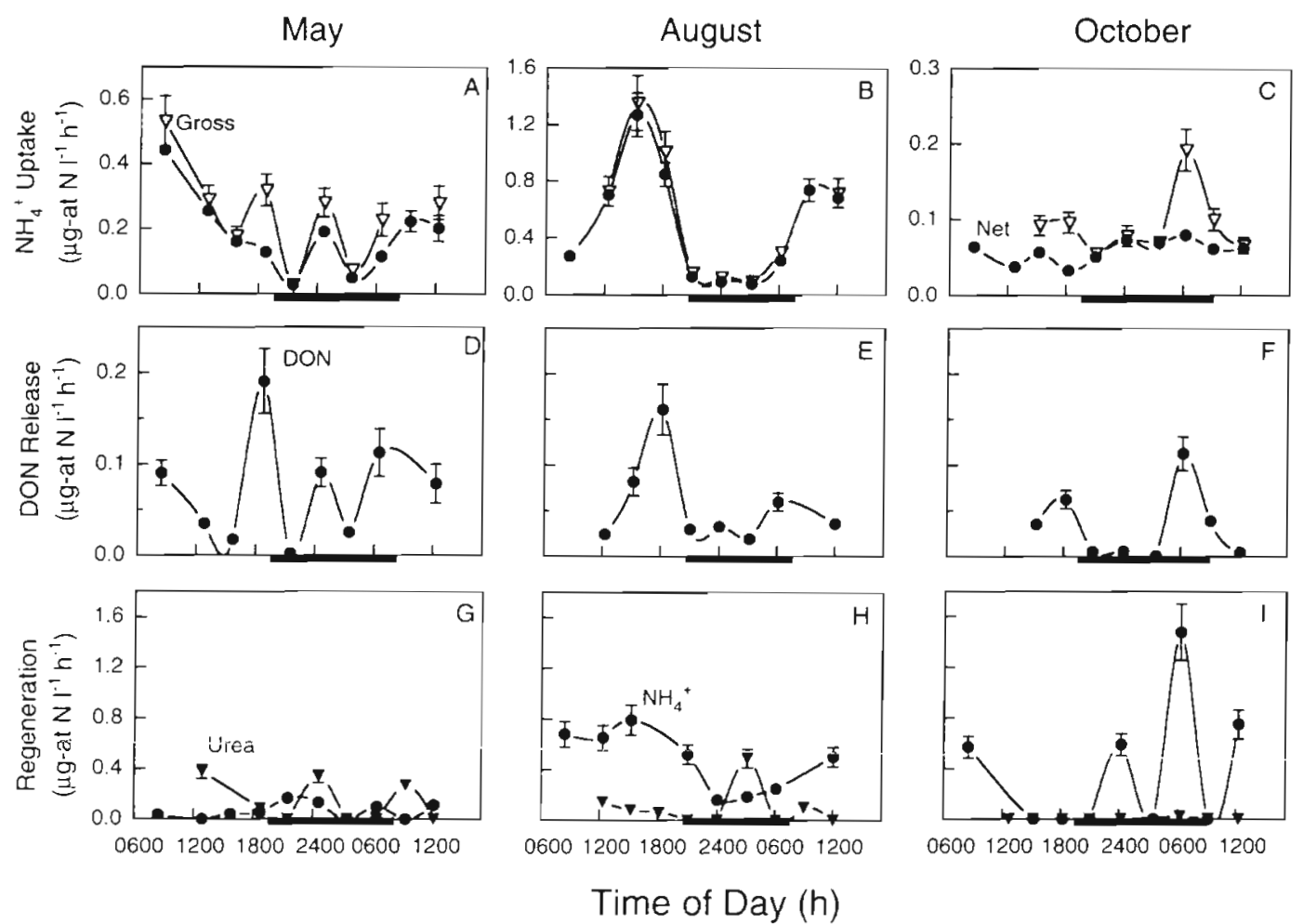

Fig. 3. Rates of (A-C) gross ( $\nabla)$ and net $(\bullet) \mathrm{NH}_{4}{ }^{*}$ uptake, (D-F) net dissolved organic nitrogen (DON) release resulting from $\mathrm{NH}_{4}{ }^{+}$ uptake (•), and $(\mathrm{G}-\mathrm{I}) \mathrm{NH}_{4}^{+}(\bullet)$ and urea (v) regeneration for 3 diel studies in the mesohaline Chesapeake Bay. Rates of DON release represent the difference between the gross and net $\mathrm{NH}_{4}{ }^{+}$uptake curves. Note that uptake rates are plotted with different scales while all DON release and $\mathrm{NH}_{4}{ }^{+}$and urea regeneration rates are plotted on the same scale. The black bars denote the dark period. Data are plotted with error bars indicating standard deviations; where error bars are not shown, error bars are smaller than the symbols 


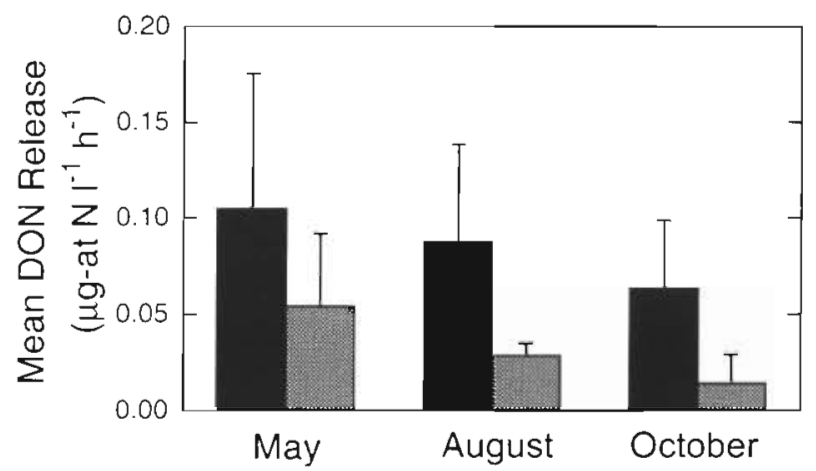

Fig. 4. Mean (+ standard deviation) rates of dissolved organic nitrogen (DON) release measured during dawn and dusk ( and at all other times of the day (浥) during 3 diel studies in the mesohaline Chesapeake Bay

tion of urea were comparable in May and August and virtually undetectable in October (Fig. 3G-I).

\section{Relationships between nitrogen uptake and release}

From season to season, the relationship between total nitrogen uptake and regeneration differed considerably, as did the percentage of each nitrogen form used and regenerated. During May and August, the ratio of total nitrogen release, $\mathrm{NH}_{4}{ }^{+}$regeneration, and urea regeneration to their respective uptake rates were all $<1$, indicating that uptake exceeded release (Table 1). In October, however, the total amount of nitrogen released and $\mathrm{NH}_{4}{ }^{+}$regenerated was -3 times greater than the amount of total nitrogen or $\mathrm{NH}_{4}{ }^{+}$ taken up. As a percentage of gross uptake, 32, 10, and $36 \%$ of the total flux of $\mathrm{NH}_{4}{ }^{+}$into cells was released as DON in May, August, and October, respectively (Table 1).

In May, $\mathrm{NH}_{4}^{+}, \mathrm{NO}_{3}{ }^{-}$, and urea contributed roughly equal proportions to total nitrogen uptake, while in

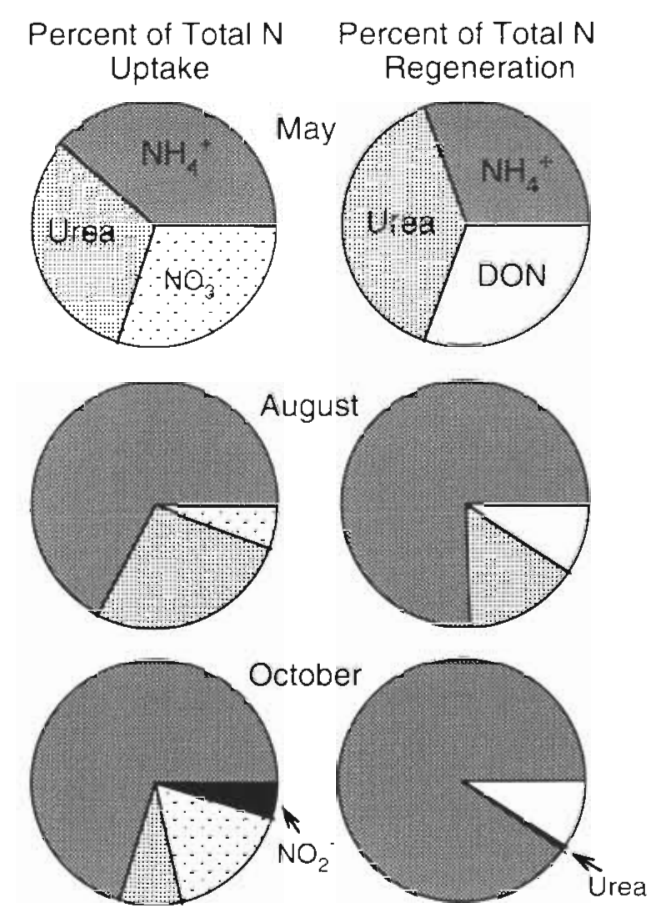

Fig. 5. Percentage of the total amount of nitrogen taken up as $\mathrm{NH}_{4}{ }^{+}$, urea, and $\mathrm{NO}_{3}^{-}\left(\mathrm{NO}_{2}^{-}\right.$uptake was only measured in October), and the percentage of the total amount of nitrogen regenerated as $\mathrm{NH}_{4}{ }^{+}$, urea, and dissolved organic nitrogen (DON) over a $24 \mathrm{~h}$ period

August and October the proportion of $\mathrm{NH}_{4}{ }^{+}$taken up exceeded all the other substrates combined (Fig. 5). Likewise, in May, urea, $\mathrm{NH}_{4}^{+}$, and DON were all released or regenerated in roughly equal proportions. However, with time, the relative release of urea declined, such that by October, the contribution of urea to regenerated nitrogen was barely detectable. The contribution of autotrophic DON release to total nitrogen release likewise decreased from May to August, and remained low in October (Fig. 5).

Seasonally, the relative proportion of nitrogen in the PN, DIN and DON pools also changed (Fig. 6). Coincident with these concentration changes were dramatic shifts in the $\mathrm{C}: \mathrm{N}$ ratio of the dissolved organic matter (DOM) pool (Table 2). In May, this ratio was 36.8 indicative of a relatively nitrogen poor mixture (Table 2). In August, however, the $\mathrm{C}: \mathrm{N}$ of the DOM pool had dropped to 8.8 , and the mean DON concentration had increased from 7 to $42 \mu \mathrm{g}$-at. $\mathrm{N}^{-1}$ (Fig. 6). By October, the concentration of the DON pool was 


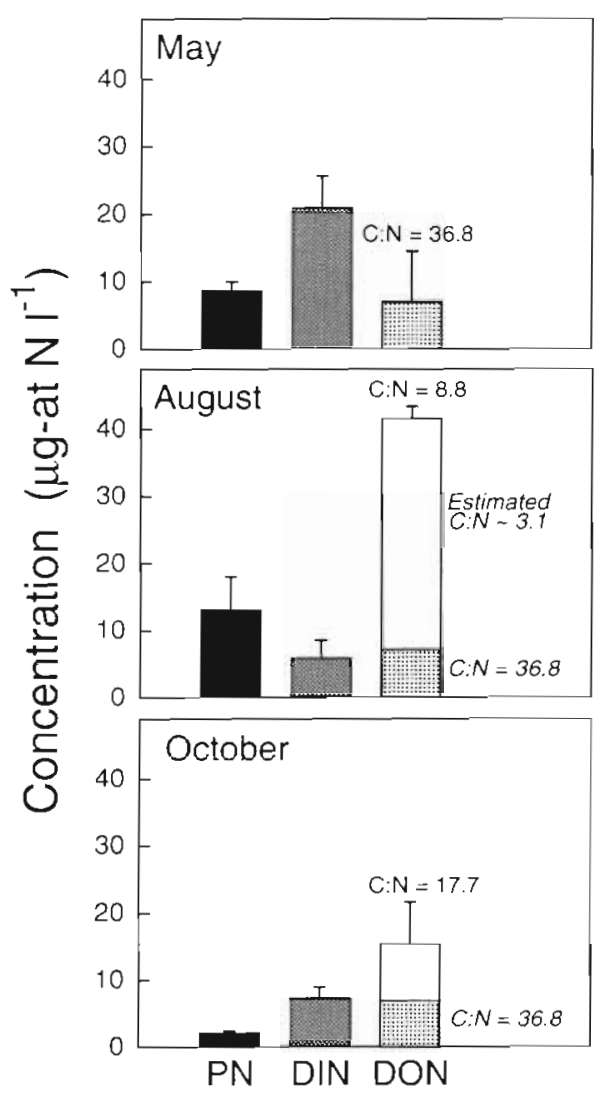

Fig. 6. Concentrations of particulate nitrogen (PN), dissolved inorganic nitrogen (DIN), and dissolved organic nitrogen (DON) during 3 diel studies in the mesohaline Chesapeake Bay. The C: $N$ ratio of the entire $D O N$ pool is given above the DON bars. The C:N ratio of the DON pool present in May is indicated during all 3 months by the light gray fill (표)

reduced by more than $50 \%$ from August, and the C:N ratio of the DOM pool had doubled to 17.7 (Table 2). The C:N ratios of the particulate material averaged 8.5 in May and 5.8 in August ( $\mathrm{C}: \mathrm{N}$ values of the particulate fraction were not available for October).

Table 2. Carbon to nitrogen molar ratios for particulate and dissolved organic fractions and various rate processes. Ratios were calculated using data from Fig. 7. Total carbon uptake includes autotrophic production and bacterial dissoived organic carbon (DOC) uptake. Total nitrogen uptake includes gross $: \mathrm{H}_{4}{ }^{+}$uptake and net $\mathrm{NO}_{3}$ and urea uptake $\mathrm{NO}_{2}$ uptake was included in October). nd: not determined

\begin{tabular}{|lcccc|}
\hline & PC & Total C uptake & DOC & DOC release \\
\cline { 3 - 5 } \cline { 4 - 5 } & PN & Total N uptake & DON & DON release \\
\hline May & 8.5 & 3.6 & 36.8 & 3.4 \\
August & 5.8 & 3.6 & 8.8 & 4.5 \\
October & nd & 22.5 & 17.7 & 4.4 \\
\hline
\end{tabular}

\section{Carbon flux}

Autotrophic production, including autotrophic DIC uptake and DOC release, was lowest in May but comparable in August and October (Table 3; Malone et al. 1991). Rates of DOC uptake and release were comparable in May and August but very low in October (Table 3; Malone et al. 1991). We estimated respiration rates for each study by calculating the difference between the carbon uptake rate measured in the $24 \mathrm{~h}$ incubation and the carbon uptake rate measured in the short-term incubation. This approach yielded estimates of respiration loss that were very similar to direct respiration measurements done in the mesohaline Chesapeake Bay in 1989/1990 by Smith \& Kemp (1995; Table 3).

\section{Turnover times}

Turnover times for $\mathrm{NO}_{3}{ }^{-}$were longest in May, when $\mathrm{NO}_{3}^{-}$concentrations were highest, and shortest in August, when $\mathrm{NO}_{3}{ }^{-}$concentrations were near the limit of detection (Table 4). Turnover times for the regenerated forms of nitrogen, $\mathrm{NH}_{4}{ }^{+}$and urea, were lowest in May and August, and increased several-fold in October (Table 4). Mean turnover times for DON were comparable to $\mathrm{NO}_{3}{ }^{-}$in the spring, and much longer than the inorganic nitrogen forms or urea in August and October (Table 4). The turnover times for DOC, at 40 to $87 \mathrm{~d}$, were 8 times longer than DON turnover times in the spring but comparable in summer and fall (Table 4).

\section{DISCUSSION}

Odum (1956) introduced the use of the ratio of autotrophic production to total community respiration as an indicator of the relative importance of autotrophy versus heterotrophy in aquatic systems. Based on this principle, Smith \& Kemp (1995) measured rates of plankton community production and respiration and concluded that the mesohaline Chesapeake Bay is primarily autotrophic in the spring and primarily heterotrophic in the summer and fall. Our results in May, August, and October are consistent with these findings. From spring to fall, we observed a switch from a system in May dominated by autotrophic processes, in which rates of total nitrogen uptake exceeded regeneration (Table 1.) and the ratio of autotrophic DON release to total release was the highest we observed (Fig. 5), to one in October dominated by heterotrophic processes, in which total nitrogen regeneration was 3 fold greater than total nitrogen uptake (Table 1) and 
Table 3. Carbon flux estimates (taken from Malone et al. 1991). Autotrophic production includes autotrophic dissolved organic carbon (DOC) uptake and DOC release. Estimated respiration rates were calculated by taking the difference between the carbon uptake rate measured in a $24 \mathrm{~h}$ incubation and the carbon uptake rate measured during a short-term $6 \mathrm{~h}$ time-course. Direct measurements of respiration made by Smith \& Kemp (1995) in the mesohaline Chesapeake Bay are supplied for comparison

\begin{tabular}{|c|c|c|c|c|c|}
\hline & $\begin{array}{c}\text { Autotrophic } \\
\text { production } \\
\left(\text { mmol } C \mathrm{l}^{-1} \mathrm{~h}^{-1}\right)\end{array}$ & 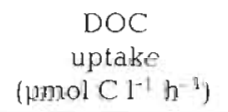 & $\begin{array}{c}\text { DOC } \\
\text { release } \\
\left(\mu \mathrm{mol} \mathrm{Cl}^{-1} \mathrm{~h}^{-1}\right)\end{array}$ & 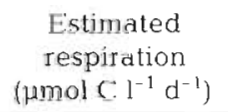 & $\begin{array}{l}\text { Smith \& Kemp } \\
\text { respiration meas. } \\
\left(\mu \mathrm{mol} \mathrm{Cl}^{-1} \mathrm{~d}^{-1}\right)\end{array}$ \\
\hline May & 2.03 & 0.146 & 0.24 & 14.1 & 16.5 \\
\hline August & 2.67 & 0.170 & 0.24 & 21.9 & 21.0 \\
\hline October & 2.67 & 0.049 & 0.014 & 28.2 & 13.5 \\
\hline
\end{tabular}

heterotrophic $\mathrm{NH}_{4}{ }^{+}$regeneration far exceeded autotrophic DON release (Fig. 5). These data provide a consistent picture of a Bay relying on allochthonous new nitrogen in the spring, and becoming increasingly reliant on autochthonous regenerated nitrogen during the transition to summer and then fall. Here we discuss our experimental assumptions, the balance between carbon and nitrogen flux rates, and provide a synthesis of how carbon and nitrogen flux rates varied with season.

\section{Experimental considerations and assumptions}

To compare heterotrophic release with autotrophic release processes, we measured release of 3 nitrogen substrates: $\mathrm{NH}_{4}^{+}$, urea, and DON. Measurements of $\mathrm{NH}_{4}{ }^{+}$and urea regeneration rates were based on isotope dilution, and therefore are measures of heterotrophic release. With these techniques, we cannot separate the contribution of bacteria from other heterotrophs. Generally, microzooplankton are responsible for the bulk of $\mathrm{NH}_{4}{ }^{+}$regenerated in a range of systems, including summer in Chesapeake Bay (e.g. Harrison 1978, Glibert et al. 1992). However, the low C:N ratio of released DON we measured suggests that

Table 4. Turnover times (mean $\pm \mathrm{SD}$ ) of $\mathrm{NO}_{3}^{-}, \mathrm{NO}_{2}{ }^{-}, \mathrm{NH}_{4}{ }^{+}$, and urea (hours) and dissolved organic nitrogen (DON) and carbon (DOC) (days) measured in the mesohaline region of Chesapeake Bay during May, August, and October. nd: not determined

\begin{tabular}{|cccc|}
\hline & May & August & October \\
\hline $\mathrm{NO}_{3}{ }^{-}$ & $120.0 \pm 21.6$ & $5.3 \pm 7.7$ & $6.0 \pm 16.8$ \\
$\mathrm{NO}_{2}{ }^{-}$ & nd & nd & $21.5 \pm 5.0$ \\
$\mathrm{NH}_{4}{ }^{-}$ & $3.4 \pm 2.4$ & $3.1 \pm 3.8$ & $45.6 \pm 14.4$ \\
Urea & $2.9 \pm 0.7$ & $7.9 \pm 7.9$ & $24.0 \pm 7.2$ \\
& & & \\
DON & $6.4 \pm 5.5$ & $48.2 \pm 27.1$ & $60.8 \pm 60.9$ \\
DOC & 53.0 & 49.0 & 87.0 \\
& & & \\
\hline
\end{tabular}

this material would be a substrate that would promote bacterial regeneration of $\mathrm{NH}_{4}{ }^{+}$(Goldman et al. 1987 . Jørgensen et al. 1993).

In contrast, the method we used to measure DON release differs substantially from the isotope dilution methods used to measure $\mathrm{NH}_{4}{ }^{+}$or urea regeneration. Our method for measuring DON release is dependent on cells becoming labeled with inorganic nitrogen (in this case, $\mathrm{NH}_{4}{ }^{+}$), so we view the DON release we measured as largely an autotrophic process. Release of DON from autotrophic cells would include such processes as direct release across the cell membranes, cell death and lysis, grazer-mediated release (i.e. sloppy feeding), and release due to autotrophic viral infection. Release by bacteria may also occur, although it would likely be a small percentage of the release from autotrophic cells.

\section{Balance between carbon and nitrogen uptake and release}

The carbon and nitrogen flux data were used to estimate a number of $\mathrm{C}: \mathrm{N}$ relationships (Table 2, Fig. 7). The C:N ratio of total carbon to total nitrogen uptake was below the Redfield ratio in May, suggesting a nitrogen sufficient plankton community (Redfield 1958; Table 2). Ratios of C:N uptake below Redfield proportions have previously been documented for the mesohaline Chesapeake Bay during spring (Glibert et al. 1995), as well as for the coast of Brazil (Metzler et al 1997), and the equatorial Pacific (McCarthy et al. 1996) during strong upwelling conditions. These low ratios may have resulted from uptake of nitrogen in excess of growth requirements (for example, diatoms have the capacity for large internal storage pools of nitrogen; Wheeler et al. 1983), light limitation of carbon uptake due to the shallow euphotic zone, or nitrogen uptake by heterotrophic bacteria. In May, a likely cause of the low $C: N$ uptake ratios was the dominance of diatoms and their capacity for maintaining large internal storage pools of nitrogen. In August, the C:N ratio for car- 
bon and nitrogen uptake was again below Redfield proportions at 3.6. In August, however, a more likely cause for the low ratios was substantial uptake of nitrogen by bacteria; bacterial productivity is at an annual maximum in the summer (Boynton et al. 1982, Malone 1992, Shiah \& Ducklow 1994). In contrast to May and August, the C:N ratio of uptake in October was 22.5, approximately 4 -fold higher than Redfield proportions (Table 2). Ratios of C:N uptake in excess of Redfield proportions, combined with the very low uptake rates,
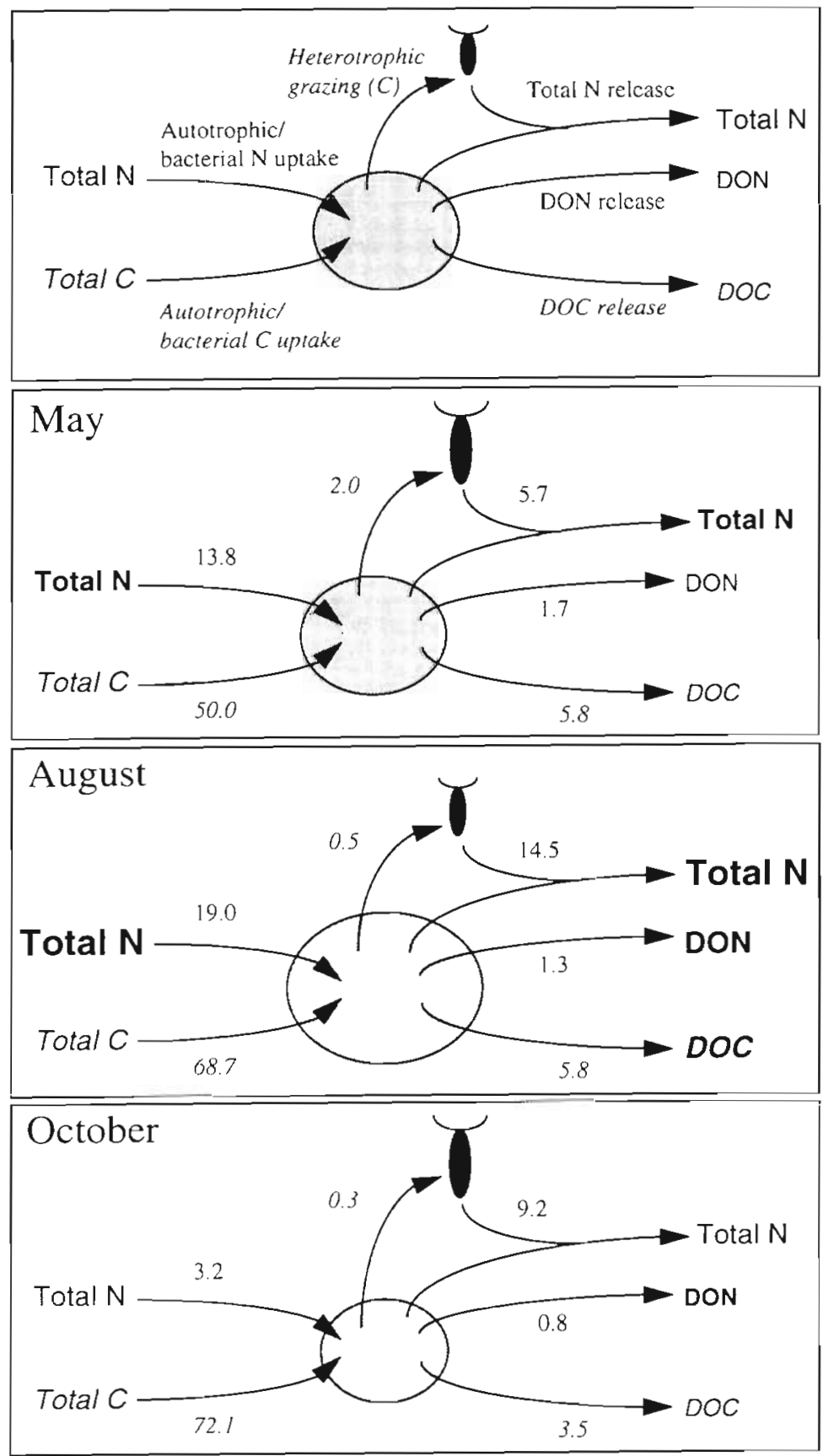

found in October, suggest a physiologically stressed assemblage.

The uptake and release of DOM appears to be seasonally out of phase, resulting in an accumulation of nitrogen-rich DOM from spring to summer and then utilization of this material from summer to fall. The $C: N$ ratio of the released DOM was very low, 3.4 to 4.5, during all 3 seasons (Table 2), which indicates release of nitrogen-rich compounds, such as DPA. The lowest mean ratio was observed in May, when concentrations of DPA were the highest measured (Fig. 1).

The low C:N ratios of DOC:DON release rates are consistent with the large changes we observed between studies in the C:N ratio of the ambient DOM pool (Fig. 6). In May, the DOM pool had a $\mathrm{C}: \mathrm{N}$ ratio of 36.8 , probably reflecting the influx of carbon-rich terrestrial or marsh-derived organic matter during the spring freshet (Table 2); for example, humic substances, a prominent component of terrestrial and marsh-derived DOM, have $C: N$ ratios ranging from 40 (Moran \& Hodson 1994) to 70 (Bano et al. 1997). By August, the C:N ratio of the DOM pool had decreased to 8.8 (Table 2). If we make the assumption that the high $\mathrm{C}: \mathrm{N}$

Fig. 7. Flow of nitrogen ( $\mu$ g-at. $\mathrm{N}^{-1} \mathrm{~d}^{-1}$ ) and carbon (umol C $\mathrm{l}^{-1} \mathrm{~d}^{-1}$; from Malone et al. 1991 . White \& Roman 1992a) over a 24 h period measured during 3 studies in the mesohaline Chesapeake Bay. We consider the flow of nitrogen and carbon driven by a combined autotrophic/bacteria ( $\square$ ) compartment and a heterotrophic grazer (T) compartment. Font and symbol sizes are indicative of the size of the pool represented. Autotrophic and bacterial nitrogen and carbon uptake were combined into 1 pool. Nitrogen flux values were integrated over $24 \mathrm{~h}$, assuming a measured rate was constant for the interval between measurements. Total nitrogen release includes $\mathrm{NH}_{4}{ }^{+}$and urea regeneration and DON release. Total nitrogen uptake includes gross $\mathrm{NH}_{4}{ }^{+}$uptake and net $\mathrm{NO}_{3}^{-}$and urea uptake $\left(\mathrm{NO}_{2}{ }^{-}\right.$ uptake was included in Ortoher). Daily DIC uptake into autotrophs was estimated by multiplying the hourly carbon fixation rate by 16 , assuming that these processes only occur in the light. Daily DOC uptake and release were estimated by multiplying the hourly rate by 24 . assuming that these processes are not dependent on a light/dark cycle. We indicate DON and DOC release coming primarily from the autotroph/bacteria fraction because of the methods we used. DON and DOC may also be released by heterotrophic grazers, but this flux would not be included in our measured rates 
DOM we measured in May was refractory and remained in the water column, the C:N of the DOM that was added to this pool from May to August would require a $C: N$ of $\sim 3.1$; this is consistent with the low $C: N$ ratios we measured for DOC:DON release. By October, the concentration of the DON pool was reduced by more than 50\% from August, and the C:N ratio of the DOM pool had doubled to 17.7. As the biota of the Bay apparently relied more on regenerated nitrogen throughout the summer, the increase in the C:N ratio of the DOM pool observed in October could be due to preferential use of nitrogen-containing organic moieties resulting in the accumulation of relatively carbon-rich DOM (Sambrotto et al. 1993).

\section{Seasonal synthesis}

Our results in May are consistent with previous observations in Chesapeake Bay which suggest that the Bay is primarily autotrophic in the spring and dependent on new $\mathrm{NO}_{3}{ }^{-}$inputs. Based on trends in chl a concentrations and primary production measured in the mesohaline Chesapeake Bay during 1988 (Malone et al. 1991), our May cruise appeared to take place during the mid to late spring bloom. Concentrations of $\mathrm{NO}_{3}{ }^{-}$were still elevated during our study and chl a concentrations were approaching the seasonal maximum ( $\left.19 \mu \mathrm{g} \mathrm{chl} \mathrm{l}^{-1}\right)$ measured by Malone et al. (1991). The spring bloom in Chesapeake Bay is usually diatom based and typically declines by mid-May due to inorganic nutrient limitation of biomass production (Sellner \& Brownlee 1988, Conley \& Malone 1992, Glibert et al. 1995). The decline of the spring bloom also tends to mark the change from a plankton community whose growth rate, as opposed to biomass accumulation, is limited by phosphorus to one limited by nitrogen (Malone et al. 1996). The high DIN:DIP ratio we measured $(249 \pm 92)$ and long turnover times of the DIN pool (120 $\pm 22 \mathrm{~h}$ for $\mathrm{NO}_{3}^{-}$alone; Table 4) are consistent with a trend towards phosphate limitation in the spring (Malone et al. 1996).

Quantitatively, more DON was released from autotrophs in May than during August or October. In parallel experiments with ours, White \& Roman (1992a) found that grazing rates were also highest in May relative to the other 2 seasons (Fig. 7). This suggests that breakage of cells during 'sloppy feeding' may have contributed to the relatively high DON release rates we measured. While grazing rates of the macrozooplankton were at a seasonal high, our measured nitrogen regeneration rates were at a seasonal low (Fig. 3G). During this time of year, however, it would be expected that the macrozooplankton would be retaining much of their incorporated nitrogen for growth and egg production (White \& Roman 1992b).

Our results in August are consistent with previous observations in Chesapeake Bay which suggest the Bay becomes increasingly heterotrophic in the summer, as well as having an increased dependence on regenerated $\mathrm{NH}_{4}{ }^{+}$(Malone et al. 1988, Smith \& Kemp 1995). As a percentage of total nitrogen regeneration, heterotrophic regeneration increased from $70 \%$ in May to over 93\% in August (Fig. 5).

The August study took place immediately after a tropical depression passed through the area. During this study, we observed patches of chl a-rich water alternating with patches of increased $\mathrm{NH}_{4}^{+}$, urea, and $\mathrm{NO}_{2}{ }^{-}$concentrations (Fig. 1B, E). Increased concentrations of $\mathrm{NH}_{4}{ }^{+}$may have been the result of sediment regeneration and then transport to the surface during the storm. Benthic regeneration rates in the mesohaline Bay are at a seasonal maximum during the summer (Kemp \& Boynton 1981), and are believed to support the summer productivity maximum in the Bay (Kemp \& Boynton 1984). The ratio of our measured $\mathrm{NH}_{4}{ }^{+}$regeneration to $\mathrm{NH}_{4}{ }^{+}$uptake was 0.86 in August, suggesting that another nitrogen source, such as release from the sediments, was necessary to sustain the plankton nitrogen demand (Table 1).

In general, Chesapeake Bay is also characterized by nitrogen limitation of biomass specific rates in the summer (Malone et al. 1996). Consistent with this scenario, DIN:DIP ratios ( 7 to 57 ) were much lower than those measured in May and, at times, even dropped below the Redfield ratio. Turnover times for DIN decreased but turnover times for organic nitrogen (urea and DON) increased (Table 4). Also, nitrogen use was less diverse, with $\mathrm{NH}_{4}{ }^{+}$being the dominant substrate used, perhaps reflecting heterotrophic bacterial utilization (Kirchman 1994). The lower mean particulate C: $N$ ratio measured in August $(5.8$ compared to 8.5 in May; Table 2) would be consistent with an increase in bacterial biomass.

The relative proportion of DON release to gross $\mathrm{NH}_{4}{ }^{+}$uptake in August was the lowest we measured at $10 \%$ (Table 1 ). This low proportion of DON release to $\mathrm{NH}_{4}{ }^{+}$uptake could be due to rapid incorporation of recently released DON, a process which was likely occurring during the warm summer month of August, particularly in view of the nitrogen-deficient status of the Bay. Alternatively, this low ratio of release to uptake could reflect the lower abundance of grazers observed during the August cruise (White \& Roman 1992a).

Our results in October are again consistent with the results of previous observations that suggest the mesohaline Chesapeake Bay is predominantly heterotrophic in the fall (Smith \& Kemp 1995). Heterotrophic 
nitrogen regeneration was 3 to 4 times higher than the primarily autotrophic nitrogen demand (Table 1). In spite of the relatively high concentrations of ambient DIN and favorable DIN:DIP ratios, nitrogen uptake rates were the lowest of the seasons studied and DON release rates were relatively high, the combination of which suggests a nutrient-stressed assemblage.

\section{Conclusions}

We were able to measure a broad suite of nitrogen and carbon fluxes in the near-surface waters of Chesapeake Bay during 3 cruises to provide a more comprehensive view of the dynamics of these pools than has been available to date. We found that water column nitrogen demand exceeded nitrogen regeneration in the spring but nitrogen regeneration was over 3 times greater than the nitrogen demand by the fall. Mean rates of autotrophic DON release were highest in May but heterotrophic release was more important in summer and fall. During all seasons, the C:N ratio of the released DOM was in the range of 3.4 to 4.5 , suggesting release of nitrogen-rich compounds such as amino acids. Release of DOM with a low C:N ratio was corroborated by observed changes in the ambient DON pool, which increased in concentration over 4 -fold while the C:N ratio of the DOM pool decreased by a factor of 4 .

These data provide a consistent picture of a system that is primarily autotrophic in the spring, but becomes progressively more heterotrophic later in the year. These data also suggest that DON is an important intermediate in this transition and serves as a link between the allochthonous nitrogen-based autotrophic production in the spring and the autochthonous nitrogen-based heterotrophic system in the summer and fall.

Acknowledgements. We thank S. Pike and B. Wendler for assistance in the field, and $\mathrm{H}$. Ducklow for the opportunity to participate in the cruises. T Fisher graciously provided the DOC data. We acknowledge helpful discussions of rate calculations with Y Collos, G. Slawyk, and P. Raimbault. This research was supported by NSF grant OCE-88-17585 to P.M.G.; NSF grani OCE-9522017 to P.M.G. and D.A.B., Sca Grant \#NA66RG0282 to D.A.B., and a post-doctoral scholarship to E.S. from the Swedish Natural Science Research Council. This is contribution number 3064 from the University of Maryland Center for Environmental Science.

\section{LITERATURE CITED}

Bano N, Moran MA, Hodson RE (1997) Bacterial utilization of dissolved humic substances from a freshwater swamp. Aquat Microb Ecol 12:233-238

Bevington PR (1969) Data reduction and error analysis for the physical sciences. McGraw-Hill, New York, p 56-65

Boynton WR, Kemp WM (1985) Nutrient regeneration and oxygen consumption by sediments along an estuarine salinity gradient. Mar Ecol Prog Ser 23:45-55

Boynton WR, Kemp WM, Keefe CW (1982) A comparative analysis of nutrients and other factors influencing estuarine phytoplankton production. In: Kennedy VS (ed) Estuarine comparisons. Academic Press, New York, p 69-90

Bronk DA, Glibert PM (1991) A ${ }^{15} \mathrm{~N}$ tracer method for the measurement of dissolved organic nitrogen release by phytoplankton. Mar Ecol Prog Ser 77:171-182

Bronk DA, Glibert PM (1993a) Application of a ${ }^{15} \mathrm{~N}$ tracer method to the study of dissolved organic nitrogen uptake during spring and summer in Chesapeake Bay. Mar Biol 115:501-508

Bronk DA, Glibert PM (1993b) Contrasting patterns of dissolved organic nitrogen release by two size fractions of estuarine plankton during a period of rapid $\mathrm{NH}_{4}{ }^{+}$consumption and $\mathrm{NO}_{2}^{-}$production. Mar Ecol Prog Ser 96: 291-299

Bronk DA, Glibert PM, Ward BB (1994) Nitrogen uptake, dissolved organic nitrogen release, and new production. Science 265:1843-1846

Collos Y (1992) Nitrogen budgets and dissolved organic matter cycling. Mar Ecol Prog Ser 90:201-206

Collos Y, Descolas-Gros C, Mornet F (1996) Diel variation in dissolved organic nitrogen in a coastal pond: relationships with carbon and nitrogen metabolism. J Exp Mar Biol Ecol 202:177-189

Collos Y, Dohler G, Biermann I (1992) Production of dissolved organic nitrogen during uptake of nitrate by Synedra planctonica: implications for estimating new production in the oceans. J Plankton Res 14:1025-1029

Conley DJ, Malone TC (1992) Annual cycle of dissolved silicate in Chesapeake Bay: implications for the production and fate of phytoplankton biomass. Mar Ecol Prog Ser 81: $121-128$

Dugdale RC, Goering JJ (1967) Uptake of new and regenerated forms of nitrogen in primary productivity. Limnol Oceanogr 12:196-206

Fisher TR, Peele ER, Ammerman JW, Harding LW Jr (1992) Nutrient limitation of phytoplankton in Chesapeake Bay. Mar Ecol Prog Ser 82:51-63

Glibert PM, Capone DG (1.993) Mineralization and assimilation in aquatic, sediment, and wetland systems. In Knowles R, Blackburn TH (eds) Nitrogen isotope techniques in plant, soil, and aquatic systems. Academic Press, New York, p 243-272

Glibert PM, Conley DJ, Fisher TR, Harding LW Jr, Malone TC (1995) Dynamics of the 1990 winter/spring bloom in Chesapeake Bay. Mar Ecol Prog Ser 122:27-43

Glibert PM, Garside C, Fuhrman JA, Roman MR (1991) Timedependent coupling of inorganic and organic nitrogen uptake and regeneration in the plume of the Chesapeake Bay estuary and its regulation by large heterotrophs. Limnol Oceanogr 36:895-909

Glibert PM, Lipschultz F, McCarthy JJ, Altabet MA (1982) Isotope dilution models of uptake and remineralization of ammonium by marine plankton. Limnol Oceanogr 27: $639-650$

Glibert PM, Miller CA, Garside C, Roman MR, McManus GB (1992) $\mathrm{NH}_{4}{ }^{+}$regeneration and grazing: interdependent processes in size-fractionation ${ }^{15} \mathrm{NH}_{3}^{-}$experiments. Mar Ecol Prog Ser 82:65-74

Goldman JC, Caron D, Dennett MR (1987) Regulation of gross growth efficiency and ammonium regeneration in bacteria by substrate C:N ratio. Limnol Oceanogr 32:1239-1252 
Hansell PA, Goering JJ (1989) A method for estimating uptake and production rates for urea in seawater using ${ }^{14} \mathrm{C}$ urea and ${ }^{15} \mathrm{~N}$ urea. Can J Fish Aquat Sci 46:198-202

Harrison WG (1978) Experimental measurements of nitrogen remineralization in coastal waters. Limnol Oceanogr 23: $684-694$

Horrigan SG, Montoya JP, Nevins JL, MCC arthy JJ, Ducklow H, Goericke R, Malone T (1990) Nitrogenous nutrient transformations in the spring and fall in the Chesapeake Bay. Estuar Coast Shelf Sci 30:369-391

Jorgensen NOG, Kroer N, Coffin RB, Yang XH, Lee C (1993) Dissolved free amino acids, combined amino acids, and DNA as sources of carbon and nitrogen to marine bacteria. Mar Ecol Prog Ser 98:135-148

Kemp WM, Boynton. WR (1981) External and internal factors regulating metabolic rates in an estuarine benthic community. Oecologia 51:19-27

Kemp WM, Boynton WR (1984) Spatial and temporal coupling of nutrient inputs to estuarine primary production: the role of particulate transport and decomposition. Bull Mar Sci 35:522-535

Kemp WM, Boynton WR (1992) Benthic-pelagic interactions: nutrients and oxygen dynamics. In: Smith DE, Leffler M, Mackiernan G (eds) Oxygen dynamics in the Chesapeake Bay - a synthesis of recent results. Maryland Sea Grant College, College Park, p 149-209

Kirchman DL (1994) The uptake of inorganic nutrients by heterotrophic bacteria. Microbial Ecol 28:255-271

Laws EA (1985) Analytical models of $\mathrm{NH}_{4}{ }^{+}$uptake and regeneration experiments. Limnol Oceanogr 30:1340-1350

Loftus ME, Subba Rao DV, Seliger HH (1972) Growth and dissipation of phytoplankton in Chesapeake Bay. I. Response to a large pulse of rainfall. Chesapeake Sci 13:282-299

López-Veneroni D, Cifuentes LA (1994) Transport of dissolved organic nitrogen in Mississippi River plume and Texas-Louisiana continental shelf near-shore waters. Estuaries 17:796-808

Malone TC (1992) Effects of water column processes on dissolved oxygen, nutrients, phytoplankton, and zooplankton. In: Smith DE, Leffler M, Mackiernan G (eds) Oxygen dynamics in the Chesapeake Bay. Maryland Sea Grant College, College Park, p 61-112

Malone TC, Conley DJ, Fisher TR, Glibert PM, Harding LW (1996) Scales of nutrient limited phytoplankton productivity in Chesapeake Bay. Estuaries 19:371-385

Malone TC, Crocker LH, Pike SE, Wendler BW (1988) Influences of river flow on the dynamics of phytoplankton production in a partially stratified estuary. Mar Ecol Prog Ser 48:235-249

Malone TC, Ducklow HW, Peele ER, Pike SE (1991) Picoplankton carbon flux in Chesapeake Bay. Mar Ecol Prog Ser 78:11-22

McCarthy JJ, Garside C, Nevins JL, Barber RT (1996) New production along $140^{\circ} \mathrm{W}$ in the equatorial Pacific during and following the 1992 El Nino event. Deep Sea Res II 43: 1065-1093

McCarthy JJ, Kaplan W, Nevins IL (1984) Chesapeake Bay nutrients and phytoplankton dynamics. 2. Sources and sinks of $\mathrm{NO}_{2}^{-}$. Limnol Oceanogr 29:84-98

McCarthy JJ, Nevins JL (1986) Utilization of nitrogen and phosphorus by primary producers in warm-core ring $82-\mathrm{B}$ following deep convective mixing. Deep Sea Res 33: $1773-1788$

McDowell WH, Cole JJ, Driscoll CT (1987) Simplified version of the ampoule-persulfate method for determination of dissolved organic carbon. Can J Fish Aquat Sci 44: $214-218$

Menzel DW, Vaccaro RF (1964) The measurement of dissolved and particulate carbon in seawater. Limnol Oceanogr 9:138-142

Metzler P, Glibert P, Gaeta S, Ludlam J (1997) New and regenerated production in the South Atlantic off Brazil. Deep Sea Res 44:363-384

Moran MA, Hodson RE (1994) Dissolved humic substances of vascular plant origin in a coastal marine environment. Limnol Oceanogr 39:762-771

Odum HT (1956) Primary production in flowing waters. Limnol Oceanogr 1:102-117

Parsons TR, Maita Y, Lalli C (1984) A manual of chemical and biological methods for seawater analysis. Pergamon Press, Oxford, p 173

Redfield AC (1958) The biological control of chemical factors in the environment. Am Sci 46:205-221

Sambrotto RN, Savidge G, Robinson C, Boyd P, Takahashi T, Karl DM, Langdon C, Chipman D, Marra J, Codispoti L (1993) Elevated consumption of carbon relative to nitrogen in the surface ocean. Nature 363:248-250

Seliger HH, McKinley WH, Biggley WH, Rivkin RB, Aspden $\mathrm{KRH}$ (1981) Phytoplankton patchiness in frontal regions. Mar Biol 61:119-131

Sellner KG, Brownlee DC (1988) Chesapeake Bay Water Quality Monitoring Program: Phytoplankton and MicroZooplankton Component Data Summary. Maryland Department of the Environment, Baltimore

Shiah FK, Ducklow HW (1994) Temperature and substrate regulation of bacterial abundance, production and specific growth rate in Chesapeake Bay, USA. Mar Ecol Prog Ser 103:297-308

Slawyk G, Raimbault P (1995) Simple procedure for simultaneous recovery of dissolved inorganic and organic nitrogen in ${ }^{15} \mathrm{~N}$-tracer experiments and improving the isotopic mass balance. Mar Ecol Prog Ser 124:289-299

Smith EM, Kemp WM (1995) Seasonal and regional variations in plankton community production and respiration for Chesapeake Bay. Mar Ecol Prog Ser 116:217-231

Valderrama JC (1981) The simultaneous analysis of total nitrogen and total phosphorus in natural waters. Mar Chem 10:109-122

Wheeler PA, Glibert PM, McCarthy JJ (1982) Ammonium uptake and incorporation by Chesapeake Bay phytoplankton: short term uptake kinetics. Limnol Oceanogr 27. $1113-1128$

Wheeler PA, Olson RJ, Chishold SW (1983) Effects of photocycles and periodic ammonium supply on three marine phytoplankton species. II. Ammonium uptake and assimilation. J Phycol 19:528-533

White JR, Roman MR (1992a) Seasonal study of grazing by metazoan zooplankton in the mesohaline Chesapeake Bay. Mar Ecol Prog Ser 86:251-261

White JR, Roman MR (1992b) Egg production by the calanoid copepod Acartia tonsa in the mesohaline Chesapeake Bay: the importance of food resources and temperature. Mar Ecol Prog Ser 86:239-249

Submitted: March 13, 1997; Accepted: January 12, 1998

Proofs received from author(s): June 8, 1998
Editorial responsibility: Fereidoun Rassoulzadegan, Villefranche-sur-Mer, France 